\title{
Absorption of serum proteins by inorganic dusts
}

\author{
B. M. JONES, J. H. EDWARDS, and J. C. WAGNER \\ Research Laboratories, Sully Hospital, Penarth, and MRC Pneumoconiosis Unit, \\ Llandough Hospital, Penarth, Glamorgan
}

\begin{abstract}
Jones, B. M., Edwards, J. H., and Wagner, J. C. (1972). Brit. J. industr. Med., 29, 287-292. Absorption of serum proteins by inorganic dusts. Four samples of coal dust of different ranks, five types of asbestos, and a sample of silica were each incubated with normal serum and with IgG and the amount of protein absorbed onto the particle surfaces was estimated. The total amount of protein absorbed by the coal samples was not related to the rank of coal, and surface absorption by the dusts did not detectably alter protein to a form capable of reacting with rheumatoid factor, the latter finding being in disagreement with the hypothesis put forward by Payne (1963) to explain the presence of rheumatoid factor in the serum of a large proportion of coal workers with pneumoconiosis.

Estimation of immunoglobulin levels after incubation of normal serum with 10 samples of coal suggested that IgG might be selectively absorbed, and RF was absorbed in preference to normal serum proteins by dust samples which had not been coated with normal serum.
\end{abstract}

Caplan (1953) described an association between rheumatoid arthritis and the presence of multiple well-defined opacities, 0.5 to $5.0 \mathrm{~cm}$ in diameter, in chest radiographs of coal workers, many of whom subsequently developed arthritis after periods as long as 10 years. A significant proportion of nonarthritic miners with characteristic radiological opacities were found to give positive results in rheumatoid factor (RF) tests (Caplan, Payne, and Withey, 1962), and the association of complicated pneumoconiosis with rheumatoid arthritis was established by the epidemiological studies of Miall et al. (1953). Wagner and McCormick (1967) showed that high levels of RF were present more often in coal miners with simple pneumoconiosis, early, moderate, and marked progressive massive fibrosis (PMF), and particularly Caplan's syndrome, than in a control group of non-miners.

Payne (1963) showed that a batch of turbineground anthracite adsorbed about $6 \mathrm{mg}$ of protein from whole human serum per gramme of dust.
Anthracite treated with normal human serum reduced the sensitized sheep cell agglutination test titres of four out of seven positive sera and reduced the latex fixation test titres of all of eight positive sera. Bovine albumin-treated anthracite had no significant effect on any serum, but bovine $\gamma$ globulin-treated anthracite reduced the sensitized sheep cell agglutination titres of four out of seven positive sera and markedly reduced the bovine $\gamma$ globulin latex fixation test titres of all eight positive sera. Normal human serum and bovine $\gamma$ globulin did not reduce the titres when added in the absence of coal dust. These findings suggested that the absorption of whole human serum, or a fraction of it, and of bovine $\gamma$ globulin on to the surface of anthracite dust particles could result in an alteration in the configuration of the protein molecules so that they become capable of reacting with RF.

Hart and Aslett (1942) found that the incidence of simple and complicated pneumoconiosis was higher in men employed in anthracite mines than in 
bituminous mines. They concluded that disease incidence was related to the rank of coal (National Coal Board, 1964).

An examination of the absorption of human serum and IgG by coal samples of different rank and of the ability of the absorbed proteins to react with RF has been undertaken to test Payne's hypothesis and to discover whether or not protein absorption by coal particles is related to their rank. Samples of asbestos and silica dust of respirable size were used for comparison.

\section{Materials and methods}

Ten samples of turbine-ground coals were kindly provided by Dr. F. Pooley' ${ }^{1}$; these are referred to as 'Barnsley' (rank 602); 'Big pit' (450); 'Daw mill' (800); 'Gedling' (802); 'Gellideg' (200), 'Kilmerston' (401); 'Meadow vein' (300); 'Pump quart' (100); 'Red vein' (300); and 'Trafalgar' (200). The average particle diameters of four of these coal samples (Barnsley, Daw mill, Meadow vein, and Pump quart, selected because of their wide range of coal ranks) were determined by optical microscopy using a micrometer eye-piece and the surface areas were computed.

The silica dust used was Microsil, while the asbestos dusts were the UICC standard reference samples comprising Rhodesian chrysotile (chrysotile A), Canadian chrysotile (chrysotile B), amosite, anthophyllite, and crocidolite.

Normal human serum was obtained by venepuncture from the investigators. Human IgG was prepared from Cohn fraction II by chromatography on a DEAEcellulose column, $2.5 \times 60 \mathrm{~cm}$, equilibrated with $0.0175 \mathrm{M}$ phosphate buffer, $\mathrm{pH} 6.5$. Samples of serum containing RF were kindly provided by Dr. J. N. McCormick ${ }^{2}$ and results presented are representative of the four samples studied.

A weighed sample of each dust was added to either $2 \%$ or $10 \%$ normal serum in $0.01 \mathrm{M}$ phosphate-buffered saline, $\mathrm{pH} 7 \cdot 4$, or to human IgG, $1.4 \mathrm{mg} \mathrm{ml}^{-1}$. The mixture was shaken and incubated at $37^{\circ} \mathrm{C}$ for 2 hours and stored overnight at $4^{\circ} \mathrm{C}$. The dust and serum were separated by filtration under vacuum using filters of 450 $\mathrm{m} \mu$ pore size, and the protein concentration of the filtrate was determined by absorption at $280 \mathrm{~m} \mu$. The value of optical density was then compared with that obtained from the normal serum to which no dust had been added. The optical densities were translated into protein concentrations using a Cohn fraction II standard.

Rates of absorption of serum proteins were measured by incubating weighed amounts of each dust $(1.0 \mathrm{~g}$ of the four coal samples and $0.5 \mathrm{~g}$ of silica and the five asbestos samples), with $10 \mathrm{ml} 2 \%$ normal serum at $37^{\circ} \mathrm{C}$ as described, but for a period of $\mathbf{3 0}$ minutes. At the end of this time each of the mixtures was filtered and the protein absorption was determined as before. Each serum sample was then re-incubated with the same sample of dust for further periods of 30 minutes.

\footnotetext{
${ }^{1}$ Mining Department, University College, Cardiff. ${ }^{2}$ Rheumatic Diseases Unit, Northern General Hospital, Edinburgh.
}

The serum-coated dust was washed by passing three 5 -ml aliquots of $0.01 \mathrm{M}$ phosphate-buffered saline, $\mathrm{pH}$ $7 \cdot 4$, through the $450 \mathrm{~m} \mu$ filter on which it had been collected and then it was incubated at $37^{\circ} \mathrm{C}$ for 2 hours and at $4^{\circ} \mathrm{C}$ overnight with a 1 in 10 dilution of the serum containing RF. After filtration of the mixture the protein concentration of the filtrate was determined from optical density measurements. The RF titre was evaluated by a sensitized sheep cell agglutination test (Ball, 1950), using sheep erythrocytes coated with heat-denatured human IgG. Results were compared with those obtained from the same high titre serum sample to which coated dusts had not been added.

Protein eluted by the washing procedure was estimated by optical density measurements and the RF level was titrated after incubating serum-containing RF with the washings. Further coated dust samples were not washed before incubation with serum containing RF.

Each of the 10 samples of coal was also incubated with $0.01 \mathrm{M}$ phosphate-buffered normal serum, $\mathrm{pH} 7.4$, and the immunoglobulin levels (IgG, IgA, and IgM) were determined using Hyland Immunoplates. RF levels were determined after incubating these samples of absorbed normal serum with serum containing RF.

\section{Results}

Figure 1 shows the amount of serum protein absorbed when different weights of dust were incubated separately with $10 \mathrm{ml}$ of $2 \%$ normal serum. For the coals, the amount of protein absorbed was proportional to the weight of coal, but this was not the case with silica or the asbestoses. The amount of protein absorbed by the four main coal samples was not related to their rank.

Figure 2 shows the rate of absorption when a weighed amount of each dust was incubated at $37^{\circ} \mathrm{C}$ with $10 \mathrm{ml}$ of $2 \%$ buffered serum. For the silica and asbestos samples the absorption increased linearly with time, reaching a maximum after a period varying from 60 to 90 minutes; the rates of absorption of the coal samples were not constant at any time during the experiment.

It was considered that a number of incubations with fresh samples of normal serum would be required to produce fully coated particles; if the dusts were not saturated when incubated with serum containing RF, any reduction in titre could be due to non-specific protein absorption rather than a reaction of RF with altered serum protein. Two incubations with $2 \%$ normal serum coated the amosite, crocidolite, and the four main coal samples so that no more protein was absorbed on the third occasion; this was not the case with silica, anthophyllite or the chrysotiles. On incubation with $10 \%$ serum, all the dusts absorbed further quantities of protein but five such incubations reduced the absorbing power to near zero (Fig. 3).

Protein estimations on the samples of serum containing RF after incubation with washed dust particles indicated that although the dusts had been 


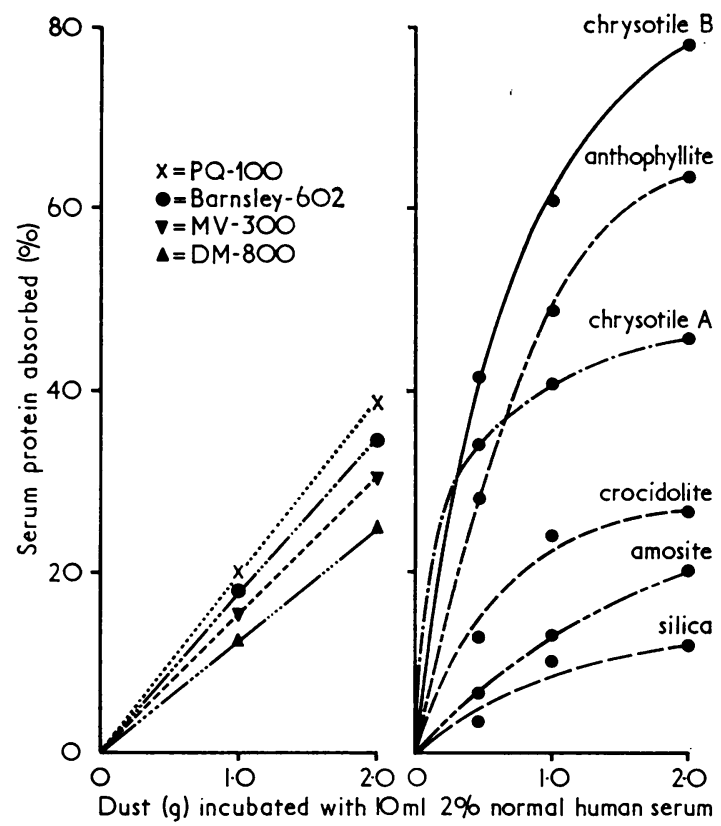

FIG. 1. Amounts of serum protein (expressed as percentages of the serum protein present before incubation) absorbed by different weights of dust. For the coal samples, the amount of absorbed protein was proportional to the weight of coal but this was not so for silica or the asbestoses. The amount of protein absorbed was not related to the rank of coal.



FIG. 2. Rates of absorption of protein by $1 \mathrm{~g}$ of coal and $0.5 \mathrm{~g}$ of silica and the five asbestos samples incubated at $37^{\circ} \mathrm{C}$ with $10 \mathrm{ml} 2 \%$ normal human serum. For the silica and asbestos samples, the absorption increased linearly with time, reaching a maximum after 60 to 90 minutes; for the coals the rates of absorption were not constant at any time during the experiment. well coated with normal serum, protein was still absorbed from the RF-containing serum (Table 1). The reductions in RF titre observed were considered to be due to non-specific uptake of RF rather than a reaction with denatured serum protein. The results shown in Table 2 indicated that normal serum protein was eluted from the surfaces of the coated particles by the washing procedure and the relatively large absorption of protein from samples of serum containing RF was probably due to the availability of sites on the dust surfaces for the absorption of more protein. The eluted protein did not react with RF to reduce the haemagglutination titre.

\section{TABLE 1}

Determinations of Protein Absorbed from Serum CONTAINING RF BY DUSTS Fully COATED WITH Normal Human Serum and then Washed

\begin{tabular}{|c|c|c|}
\hline Dust & $\begin{array}{l}\% R F \text { serum } \\
\text { protein absorbed }\end{array}$ & $\underset{\text { titre }}{\text { Reciprocal of } R F}$ \\
\hline $\begin{array}{l}\text { Control } \\
\text { Pump quart } \\
\text { Meadow vein } \\
\text { Barnsley } \\
\text { Daw mill } \quad . \\
\text { Silica } \\
\text { Amosite } \quad . \\
\text { Crocidolite } \\
\text { Chrysotile A } \\
\text { Chrysotile B } \\
\text { Anthophyllite }\end{array}$ & $\begin{array}{l}0 \\
23 \cdot 6 \\
20 \cdot 9 \\
25 \cdot 5 \\
21 \cdot 8 \\
25 \cdot 5 \\
35 \cdot 5 \\
40 \cdot 9 \\
59 \cdot 1 \\
61 \cdot 8 \\
42 \cdot 7\end{array}$ & $\begin{array}{r}1280 \\
320 \\
320 \\
640 \\
320 \\
160 \\
80 \\
20 \\
0 \\
0 \\
20\end{array}$ \\
\hline
\end{tabular}

RF titres were less than the control unabsorbed serum containing RF, but this was possibly due to non-specific protein absorption after removing normal protein by the washing procedure.

TABLE 2

Determinations of Normal Human Serum Protein Eluted from Fully CoATEd Dusts by 5-ml Aliquots of 0.01M Phosphate-Buffered Saline, PH $7 \cdot 4$

\begin{tabular}{l|c|l}
\hline \multicolumn{1}{c|}{ Dust } & $\begin{array}{c}\text { \% Surface } \\
\text { absorbed protein } \\
\text { eluted in washings }\end{array}$ & $\begin{array}{c}\text { Protein conc. } \\
\text { of washings }\end{array}$ \\
\hline Pump quart & 69 & $0.60 \mathrm{mg} \mathrm{ml}^{-1}$ \\
Meadow vein & 57 & 0.50 \\
Barnsley . & 63 & 0.62 \\
Daw mill .. & 44 & 0.56 \\
Silica & 27 & 0.45 \\
Amosite . & 53 & 0.74 \\
Crocidolite & 39 & 0.70 \\
Chrysotile A & 21 & 0.85 \\
Chrysotile B & 33 & 1.01 \\
Anthophyllite & 24 & 0.69 \\
\hline
\end{tabular}



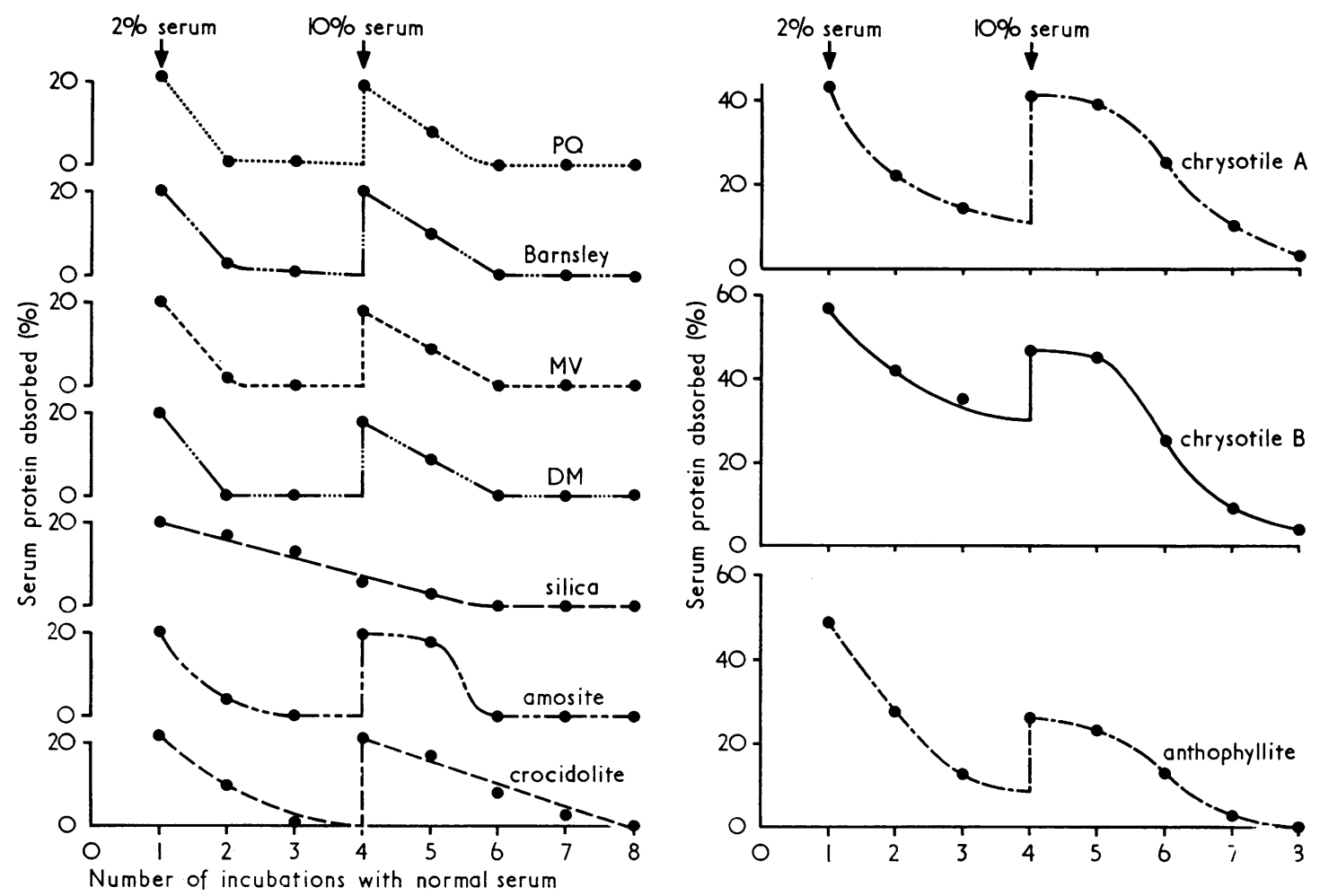

FIG. 3. Percent normal serum protein absorbed by $1 \mathrm{~g}$ of coal and $0.5 \mathrm{~g}$ of silica and asbestos samples when incubated $\times 3$ with $2 \%$ serum and then $\times 5$ with $10 \%$ serum. Profiles of absorption for the coals were quite different from those of the asbestoses; silica was unique in that extra protein was not absorbed on incubation with $10 \%$ serum.

Table 3 shows that when samples of dust were coated with normal serum but not washed with buffer before incubation with serum containing RF, only small amounts of protein were absorbed and haemagglutination titres were the same as for the unabsorbed serum or were insignificantly reduced. There was no correlation between the amount of protein absorbed by three incubations with $10 \%$ normal serum and the rank of coal, even when account was taken of the surface area of the dust particles (Table 4).

The amounts of protein absorbed by the dusts after three incubations with IgG $\left(1.4 \mathrm{mg} \mathrm{ml}^{-1}\right)$ and the haemagglutination titres of serum containing $\mathrm{RF}$ after incubation with the coated dusts are shown in Table 5. Once again there was no correlation between the rank of coal and the amount of protein absorbed and none of the dusts appeared to modify IgG to a form capable of reacting with RF. IgGcoated dusts were washed as before with $5-\mathrm{ml}$ aliquots of phosphate-buffered saline but IgG was eluted in too small a concentration for the effect on RF to be measured.
TABLE 3

Determinations of Protein Absorbed from Serum CONTAINING RF BY FUlly COATED BUT UNWASHED Dusts

\begin{tabular}{|c|c|c|}
\hline Dust & $\begin{array}{c}\% R F \text { serum } \\
\text { protein absorbed }\end{array}$ & $\underset{\text { titre }}{\text { Reciprocal of } R F}$ \\
\hline $\begin{array}{l}\text { Control .. } \\
\text { Pump quart } \\
\text { Meadow vein } \\
\text { Barnsley . } \\
\text { Daw mill .. } \\
\text { Silica } \quad . \\
\text { Amosite } \quad . \\
\text { Crocidolite } \\
\text { Chrysotile A } \\
\text { Chrysotile B } \\
\text { Anthophyllite }\end{array}$ & $\begin{array}{r}0 \\
9 \cdot 0 \\
11 \cdot 6 \\
6 \cdot 5 \\
12 \cdot 8 \\
7 \cdot 7 \\
15 \cdot 4 \\
24 \cdot 4 \\
28 \cdot 0 \\
25 \cdot 6 \\
20 \cdot 5\end{array}$ & $\begin{array}{r}1280 \\
1280 \\
1280 \\
1280 \\
1280 \\
1280 \\
640 \\
640 \\
640 \\
640 \\
640\end{array}$ \\
\hline
\end{tabular}

RF titres were the same as the control untreated serum or were reduced by only one titration tube.

Immunoglobulin levels in $1 \mathrm{ml}$ of phosphatebuffered normal serum incubated with $0.5 \mathrm{~g}$ of each 
TABLE 4

Amounts of Protein Absorbed per Gramme of Dust InCubated $\times 3$ With $10 \%$ Normal Serum

\begin{tabular}{|c|c|c|c|}
\hline Dust & Rank & $\begin{array}{c}\text { Approx. } \\
\text { surface area } \\
\left(\mu^{2}\right)\end{array}$ & $\begin{array}{c}\text { mg Serum } \\
\text { protein } \\
\text { absorbed } / g \text { of } \\
\text { dust }\end{array}$ \\
\hline $\begin{array}{l}\text { Pump quart } \\
\text { Meadow vein } \\
\text { Barnsley } \\
\text { Daw mill } \\
\text { Silica } \\
\text { Amosite } \\
\text { Crocidolite } \\
\text { Chrysotile A } \\
\text { Chrysotile B } \\
\text { Anthophyllite }\end{array}$ & $\begin{array}{l}100 \\
300 \\
602 \\
800 \\
- \\
- \\
- \\
- \\
- \\
-\end{array}$ & $\begin{array}{l}1550 \\
2400 \\
1190 \\
1650 \\
- \\
- \\
- \\
- \\
- \\
-\end{array}$ & $\begin{aligned} 4.54 & (0.0029) \\
5.06 & (0.0021) \\
5.08 & (0.0043) \\
4.66 & (0.0028) \\
8.50 & \\
12.09 & \\
12.01 & \\
28.64 & \\
30.84 & \\
21.72 & \end{aligned}$ \\
\hline
\end{tabular}

Approximate surface areas of the coal dust particles are shown and figures in parentheses indicate $\mathrm{mg}$ protein absorbed per unit surface area.

TABLE 5

Amounts of Protein Absorbed per Gramme of Dust INCUBated With IgG, $1.4 \mathrm{mg} \mathrm{ml}^{-1}$

\begin{tabular}{|c|c|c|}
\hline Dust & $\begin{array}{c}\text { mg IgG absorbed/g } \\
\text { of dust }\end{array}$ & $\begin{array}{c}\text { Reciprocal of } R F \\
\text { titre }\end{array}$ \\
\hline $\begin{array}{l}\text { Control .. } \\
\text { Pump quart } \\
\text { Meadow vein } \\
\text { Barnsley } \\
\text { Daw mill .. } \\
\text { Silica } \\
\text { Amosite . } \\
\text { Crocidolite } \\
\text { Chrysotile A } \\
\text { Chrysotile B } \\
\text { Anthophyllite }\end{array}$ & $\begin{array}{l}0 \\
4 \cdot 82 \\
4 \cdot 14 \\
4 \cdot 98 \\
5 \cdot 00 \\
12 \cdot 54 \\
12 \cdot 36 \\
19 \cdot 20 \\
40 \cdot 72 \\
47 \cdot 32 \\
25 \cdot 92\end{array}$ & $\begin{array}{l}1600 \\
1600 \\
1600 \\
1600 \\
1600 \\
1600 \\
1600 \\
1600 \\
1600 \\
1600 \\
1600\end{array}$ \\
\hline
\end{tabular}

Protein was not absorbed from serum containing RF by the IgG-coated dusts, and RF titres were the same as the control untreated serum.

of the 10 coal samples are shown in Table 6 . No absorption of IgA or IgM occurred but coal samples of high rank did absorb IgG. The treated serum samples did not react with RF.

\section{Discussion}

Previous studies have suggested that coal dust particles alter surface-absorbed serum protein to a form capable of reacting with RF (Payne, 1963), and this finding led to the development of an hypothesis which attempted to explain the presence of RF in the serum of a large proportion of coal workers with pneumoconiosis. However, the present study does
TABLE 6

IMMUNOGLOBULIN LeVels IN $1 \mathrm{ml}$ OF NORMAL SERUM AFTER INCUBATION WITH $0.5 \mathrm{~g}$ OF THE 10 COAL SAMPles

\begin{tabular}{ll|r|r|r|r}
\hline \multicolumn{1}{c|}{ Dust } & & Rank & IgG & IgA & IgM \\
\hline Control &. & & 100 & 100 & 100 \\
Pump quart & $\ldots$ & 100 & 77 & 110 & 100 \\
Gellideg &. & 200 & 75 & 102 & 102 \\
Trafalgar &. & 200 & 73 & 110 & 110 \\
Meadow vein &. & 300 & 82 & 123 & 110 \\
Red vein &. & 300 & 75 & 115 & 110 \\
Kilmerston &. & 401 & 75 & 110 & 98 \\
Big pit . &. & 450 & 88 & 115 & 102 \\
Barnsley &. & 602 & 108 & 115 & 110 \\
Daw mill &. & 800 & 121 & 123 & 115 \\
Gedling &. & 802 & 108 & 115 & 110 \\
& & & & & \\
\hline
\end{tabular}

Results are expressed as percentages of the control untreated normal serum. IgA and IgM were not absorbed but IgG levels were lower than the control serum except after incubation with the three samples of lowest rank.

not confirm Payne's findings and it is thought that the reduction in RF levels he observed on incubating normal serum-coated anthracite dust with serum containing RF was due to previous removal of surface-absorbed protein by a washing procedure. Parts of the particle surface would then be available for non-specific absorption of protein, including RF, and results similar to those shown in Table 1 would be obtained.

Results shown in this table did suggest that RF might be selectively absorbed by the incompletely coated asbestos samples as the reductions in titre were too high to be explained by the amount of protein removed, e.g., for anthophyllite to reduce the titre from $1 / 1280$ to $1 / 20,98 \cdot 5 \%$ of the RF would have to be removed, whereas only $42.7 \%$ of the total serum protein was absorbed. Less RF was absorbed by the incompletely coated coal and silica samples, but the results again suggested that RF was absorbed in preference to normal serum proteins.

The absorption of RF by the chrysotile and anthophyllite asbestos samples is of particular interest. Turner-Warwick and Parkes (1970) found a significant incidence of RF in the serum of asbestos workers which seemed to correlate with the intensity of exposure. In view of this our findings require further study.

IgG appeared to be bound more readily to coal particles than IgA or IgM, although the three samples of lowest rank appeared not to absorb IgG from whole serum (Table 6). However, all coal samples tested, and asbestos and silica, did absorb purified IgG.

No evidence was obtained in the course of these studies to suggest that the rank and absorbing 
properties of the coal dusts were related, and it seems likely, therefore, that protein absorption and denaturation are not factors that account for the different incidences of pneumoconiosis in high and low rank coal mines reported by Hart and Aslett (1942). Recent results have in fact indicated that there is no correlation between rank of coal and incidence of pneumoconiosis when the respirable mass of dust is taken into account (Jacobsen, Rae, Walton, and Rogan, 1971).

Alternative hypotheses that might explain the increased occurrence of RF in coal workers with pneumoconiosis have recently been suggested: McCormick (1971) described ways in which an IgG-like antigen on the human basement membrane might be exposed as a result of non-specific lung damage and fibrosis, and this might lead to the formation of RF. Also, altered IgG present in the body might produce higher titres of RF if coal is also present, due to a similar adjuvant effect to that observed with silica particles (Askonas and Jaroskova, 1970).

In vitro studies of protein absorption by coal and other inorganic dusts do not reproduce the situation in the lungs, where enzyme activity and cellular involvement, particularly ingestion by macrophages, may play a part in the production of RF, and the time-scale used experimentally hardly reflects the length of time dust may remain in the lungs. However, it is considered that denaturation of proteins to a form capable of reacting with RF does not occur under the experimental conditions employed in this study.

B.M.J. was supported by a grant from the University Hospital of Wales Management Committee. The authors would like to thank Dr. J. C. Gilson and Dr. V. Timbrell for their valuable comments, and the able technical assistance of I. Bidois and D. Llewellyn is gratefully acknowledged.

\section{References}

Askonas, B. A., and Jaroskova, L. (1970). Antigen in macrophages and antibody induction. In Mononuclear Phagocytes, edited by R. van Furth, pp. 595-612. Blackwell Scientific Publications, Oxford.

Ball, J. (1950). Serum factor in rheumatoid arthritis agglutinating sensitised sheep red cells. Lancet, 2, 520-524.

Caplan, A. (1953). Certain unusual radiological appearances in the chest of coal-miners suffering from rheumatoid arthritis. Thorax, 8, 29-37.

- Payne, R. B., and Withey, J. L. (1962). A broader concept of Caplan's syndrome related to rheumatoid factors. Thorax, 17, 205-212.

Hart, P. D. A., and Aslett, E. A. (1942). Chronic pulmonary disease in South Wales coalminers: medical survey. Spec. Rep. Ser. med. Res. Coun. (Lond.), No. 243, pp. 1-202. H.M.S.O., London.

Jacobsen, M., Rae, S., Walton, W. H., and Rogan, J. M., (1971). Proc. 3rd Internat. Symp. Inhaled Particles. (In press.)

McCormick, J. N. (1971). Unpublished observations.

Miall, W. E., Caplan, A., Cochrane, A. L., Kilpatrick, G. S., and Oldham, P. D. (1953). An epidemiological study of rheumatoid arthritis associated with characteristic chest $\mathrm{X}$-ray appearances in coal workers. Brit. med. J., 2, 1231-1236.

National Coal Board (1964). The Coal Classification System used by the National Coal Board. National Coal Board, London.

Payne, R. B. (1963). Rheumatoid pneumoconiosis-A clinical radiographic and serological survey. M.D. thesis, University of Wales.

Turner-Warwick, M., and Parkes, W. R. (1970). Circulating rheumatoid and antinuclear factors in asbestos workers. Brit. med. J., 3, 492-495.

Wagner, J. C., and McCormick, J. N. (1967). Immunological investigations of coalworkers' disease. J. roy. Coll. Physcns Lond., 2, 49-56.

Received for publication July 29, 1971. 